\title{
USAmerican Studies in the United Kingdom
}

\section{(2) OpenEdition}

\section{Journals}

Édition électronique

URL : https://journals.openedition.org/ejas/448

DOI : $10.4000 /$ ejas.448

ISSN : 1991-9336

Éditeur

European Association for American Studies

\section{Référence électronique}

Richard Ellis, «USAmerican Studies in the United Kingdom », European journal of American studies [En ligne], 1-1 | 2006, document 21, mis en ligne le 12 janvier 2006, consulté le 21 septembre 2021. URL : http://journals.openedition.org/ejas/448 ; DOI : https://doi.org/10.4000/ejas.448

Ce document a été généré automatiquement le 21 septembre 2021.

Creative Commons License 


\section{USAmerican Studies in the United Kingdom}

It is first necessary to lay down some framing parameters to the study of the USA in the UK's Higher Education (HE) institutions-its Universities and Colleges:

-A 2004 article in The Guardian by Polly Toynbee, widely read around the world

-the introduction of "top-up" fees which UK and EU citizens wishing to enter UK HE

-USAmerican Studies' "critical mass" in any one institution;

-the quinquennial government-imposed "Research Assessment" Exercise-aka the RAE

-the British Association of American Studies (BAAS)

-issues of gender and socio-economic class

-the barrier of the common language

-the Atlantic Ocean, aka "the pond" by many Anglo-Americans.

It is disappointing to have to begin with Polly Toynbee's Guardian article, "A degree in bullying and self-interest? No thanks," ${ }^{1}$ which was both superficially researched and highly misleading, but there is little choice in this matter. I have lost count of the number of times that European-based USAmericanists and-even-US-based USAmericanists have raised the issue of Toynbee's Guardian article. ${ }^{2}$ Toynbee argued that UK late-adolescents were turning away from USAmerican Studies, put off by the Bush government's global policies. Though rebuttals of Toynbee's argument did appear, in letters to the editor of the Guardian, these generally went unremarked outside of the UK. What was repeatedly picked up on was how Toynbee, in her article, noted that the gross number of applications to UK universities by students wishing to study 'American Studies' had fallen, according to the (reliable) UK's University Central Admissions System. Toynbee then went on to speculate as to why this reduction might have occurred, and jumped to the convenient and not implausible conclusion that the decline was the consequence of an anti-American backlash of a kind. In particular Toynbee took the reduction in applications to be the consequence of the US invasion of Iraq as part of its war on terror. Were this to be simply the case, then such a decline would need to frame my argument, as it would imply a re-orientation in the interests 
and engagement of young adult aspirants to higher education in the UK-a turning away from American Studies as a subject of study which would have considerable implications for the subject.

11 Conventionally, young adults have been the main source from which USAmerican Studies draws its recruits (the UK's HE intake is now nearing $50 \%$ of eighteen- to twenty-year olds). Indeed, the UK's young adults have consistently taken an interest in the products and productions of US individuals, groups, companies and multinationals since 1945. In this post-war period these interests have ranged eclectically, taking in: refreshments, from Hershey bars through Coke and Big Macs to Starbucks and M\&Ms (formerly, in the UK, Smarties); popular music, from Glen Miller and bebop through Elvis Presley, Bob Dylan, Janis Joplin and Jim Morrison to Madonna, rap and the Strokes; films and TV, from "I Love Lucy", "The Lone Ranger", "Rebel without a Cause" and "The Wild Ones" through "Easy Rider", "Apocalypse Now", "Star Trek" and "MASH" to "Friends", "Kill Bill" and "Violence in America"-many of these glitzed up by Hollywood's commercial rituals (like the Oscars, Disneyland and their attendant processes of celebrification); its love of addictive drugs (from Tennessee whiskey and Camel to Budweiser and Marlboro Lights via many other recreational and more or less severely demonized drugs); its writing and visual arts, from Catcher in the Rye through the Beats and The Bell Jar to Bret Easton Ellis and Toni Morrison and from abstract expressionism through Andy Warhol and photo-realism to graffiti art; its often ideologically-loaded material cultural innovations, from Levi jeans, ever-higher skyscrapers and ever-larger hypermarkets to defense architecture, gated communities and ghettoes; its environmental excess, from Silent Spring and Cadillacs through Earth House Hold, air-conditioned shopping malls, ever-wider freeways and hogged Harley Davidsons to eco-fascism, the murder of the Kyoto agreement and Hummers; its inability to contain its endless diversity by any ideological device, be that melting pots, salad bowls or multiculturalism's warm but problematic embrace; its (often related) display of and (often but not always) celebration of rebellion and free speech on the one hand and guns, capital punishment and censorship (that of the moral majority or that of the "politically correct") on the other; its deep love of anarchy (no government at all) and of ideological institutions (family, religion, high school, the stars and stripes, States Rights and apple pie). Do I contradict myself? "Very well then I contradict myself", for America is "large", it does contain "multitudes". ${ }^{3}$

12 This catalog, a heady admixture of glamour and dissent, youthfulness and exploitation, could be extended for pages. Somewhere in this catalog, the vast majority of UK citizens will encounter something that hooked them or alienated them (or both) in their late teens. Never knowing what to make of USAmerica, Amerika or Amerikkka, often fearing it, sometimes loving it, wanting to visit it and love/hating it when there. Immediately, it becomes clear that an event like Iraq and a President like George W. Bush are not going to effect a cultural sea-change of the kind Toynbee proposes. Indeed, she conceded in her article that "opinion polls make it clear that people are well able to separate their feelings about Americans from the politicians and policies now occupying the White House." ${ }^{4}$ America's allures and alarms continue to attract interest-if often in an increasingly wary way. UK late-adolescents still want to try to get to grips with its multiplicity, and any burgeoning anti-USAmericanism is countered, more or less, by such a response. Yet it is not that Toynbee was wholly wrong in proposing that the Iraq intervention was a turn-off. The Iraq intervention was and is unpopular in the UK, and Tony Blair suffered from this in the UK's 2005 General 
Election because of his administration's support for the policy. Would-be USAmerican Studies students probably did decline in number as a result. But only slightly; antiUSAmericanism is not new, but nor is it monolithic and in the UK, as in most of Europe, contradictory feelings and responses to USAmerica are entertained simultaneously by subjects only partly or poorly interpellated into the USAmerican dream's increasingly residual and diluted discourses.

Consequently, though most USAmerican Studies courses in the UK still fill up each year, they fill up slightly less readily, as USAmerica's exceptionalist myth looses its grip on the popular imagination. There have been some American Studies program closures, but these mostly predated Iraq and were the consequence of other factors, such as the ending of free higher education and the introduction of student "top-up" fee-fees that grow ever-larger and come to seem more prohibitive to almost all students, except for those from the most affluent backgrounds. Such top-up fees hit USAmerican Studies hard because students majoring in the subject are almost always required to undertake a fourth year of study in the United States. Their debts, consequently, become roughly $25 \%$ higher. ${ }^{5}$ This leads on to issues of class, which I will turn to later in my article. Already, I think, by raising the issue of affordability, I have drawn much closer to defining the core cause of the decline in numbers of applications for American Studies degree courses.

14 This decline in demand for places on USAmerican Studies courses in the UK, driven mostly by the introduction of top-up fees, relatively small though it is, matters very much, because it has weakened the position of the groups of staff teaching USAmerican Studies in the UK. I will return to this theme, but it is worth noting at this point that the position of American studies teachers is often always already weakened by the fact that they are not located in a single administrative unit-usually in UK HE such units are called "Departments"-but instead constitute a loose coalition of staff with a common interest in USAmerica drawn from several different departments. As such these USAmerican Studies staff are not in control of, nor have much influence over, decisions about how to allocate resources. For example, if the loose coalition of USAmericanists in an institution draws on staff from the Departments of History, English, Politics, Geography and Cultural Studies in a University-a not untypical coalition-and one of these staff, say the only Americanist in the Geography department, retires, then it is difficult to ensure that the interests of American Studies are effectively represented in that Department. The Geography department may feel that the higher number of students applying to do Development Studies justifies an appointment in this area of expertise, rather than American Studies, without fully appreciating the knock-on consequences-the negative impact on American Studies.

The issue here is one of critical mass. Often, in the UK, a program in USAmerican Studies is not quite large enough to warrant the establishment of a new Department, and then the determination of the economic in the last instance becomes an important consideration (if you will excuse this Althusserian outburst). Though, for convenience, the rest of this article will speak of American Studies "Departments", instead of resorting to any more awkward formulation, such as "American Studies Departments or 'subject groups' of staff," it is important to bear in mind that very often-indeed, usually-USAmericanists in the UK do not enjoy the protection of being located inn a single Department-that is to say, a discrete, (semi-)autonomous unit (a problem held in common with most UK Area Studies "subject groups of staff"). Such infra-structural 
fragility makes American Studies vulnerable to course closure, not least because, if the subject is shut-down, redundancies can be minimalized, as the group of staff return to teaching "special options" in their "home" departments.

The ever-present risk in all this is that, overall, USAmerican Studies' community of scholars in the UK becomes too small and dispersed to sustain American Studies, with the attendant risk that USAmerican Studies might cease to be fully self-sustaining at the national level. This in itself does not have to be a bad thing : perhaps American Studies generally should seek to be more international, and in seeking to be more international, resist any process by which the ASA might consciously or unconsciously set the agenda along US-centric lines as it internationalizes itself with growing determination and stamina. One thing I do have in mind here is the idea that the European Association of American Studies needs more frequently to consider how it might function internationally, beyond its biennial conferences and the establishment of the European Journal of American Studies. Perhaps EAAS needs to operate in a more concertedly international way-for example, by brokering international collaborations: research and staff and student exchanges, for example, that are not myopically dependent on regarding the US as the inexorable hub of all such exchanges. Just as, in David Crystal's argument, "English is now so widely established" around the globe "that it can no longer be thought of as "owned"," 6 so, it might be argued, "America" is not just American and "the American" is not just America's (not least because USAmerica is not all of America). Perhaps a more global understanding of what is America and what is American would prove more attractive to students and help prevent course closures at a time when Development Studies, Migration Studies, Diaspora Studies and Globalization Studies are generally growing in popularity. This drift away from Area Studies to other kinds of transnational study has been emerging in the UK for some time, reducing the viability of USAmerican degree programs.

One possible other factor contributing to American Studies program closures in the UK, however, has been the government-imposed research assessment exercise-the RAEand this brings me to my next framing parameter. The UK's RAE has proved to be highly controversial and it is a strange and difficult activity to describe briefly. Its objective is clear, however: it seeks to ensure that UK government research funding is directed towards those higher education institutions that will most benefit from and make the best use of such financial support, in order to sustain and develop academic research. The RAE seeks to achieve this by assessing research quality, institution by institution, discipline by discipline, subject by subject. What has proved contentious in all this is whether the RAE has succeeded in doing what it seeks to do. A widespread feeling in the UK is that instead, by erecting sets of criteria by which it measures "quality", "benefit" and "best use", the RAE has somehow distorted or diluted the research being undertaken in UK higher education.

The RAE has certainly resulted in an extension of funding. Institutions previously excluded from receiving any direct (as imposed to competition-driven) government funding now receive at least some block grant funding, if they cross over the RAE's quality threshold, when before 1991 they did not. Be it noted I am talking of dozens and dozens of such institutions. Increasingly, as well, "peers" have, during the RAE, examined UK academic research and judged it to be improving in quality, while, at the same time, the quantity of research being carried out has also risen. These "peers" are large in number-a typical RAE panel drawn up to judge any particular subject consists 
of over a dozen senior academics-and these panelists have almost never reported any concerns about the RAE process (or if they do have concerns, they have concealed them). All this could be taken as a measure of the RAE's success (though since the numbers of academics undertaking research has risen sharply to cater for increased student intakes in the UK, such an extrapolation may not be as valid as first appears).

On the other hand, academics frequently contend that certain types of research have suffered a decline. Since the RAE is a quinquennial exercise, this decline is alleged to have occurred in relation to "large" projects, which take more than five years to reach fruition and which take up all the research energies of the researcher(s). Such "large project" researchers would have difficulty in meeting the RAE's quinquennial timetable, which in turn inevitably shapes its criteria to some extent. Thus, it is argued, such researchers become handicaps during the assessment exercise. The argument therefore runs that such researchers may therefore, by choice, or by diktat, choose not to undertake such time-consuming research (despite the RAE administrators' repeated explicit statements that it is not the intention of the RAE to discourage such research). On the other hand, at the other extreme, the RAE's criteria do direct its assessors to view "survey" type publications (such as this one!), with little or no academic "research" contained within them, as not warranting a high rating (so making such "outcomes" a handicap in an unambiguous way). If my Department knew I was spending my time writing this essay, the argument runs, they would be discouraging me from doing so!

Yet these fears do not seem to be borne out. I do not detect any important reorientation or diminution of any "large project" or "survey" types of research and/or publication being undertaken by UK-based researchers. Nor do I sense that academics are churning out research of a sub-standard variety to meet RAE-imposed targets (another common accusation). The RAE, however, does seem to have impacted upon American Studies in quite another, more unanticipated way, and this is above all else why it deserves to be set up as a framing parameter when considering the situation of USAmerican Studies in the UK. The RAE has always sought to ensure that different subject areas (English, History, Geography, French, American Studies) are treated comparably when assessing research quality and the research environments ("research culture") in which such research is pursued. In the RAE quinquennial exercise for 2001, for example, the RAE managers went so far as to establish a checking procedure to ensure comparability between different subject areas-known as Units of Assessment or UoAs. The aim was to ensure that each UoA's assessment was equally rigorous-no more and no more less. This was easy to do when, nationally, the 'UoA' was large (History, say, or Sociology). "Smoothing", as it might be labeled, was relatively easy to do. But UoAs like American Studies were not large. Only thirteen "departments" entered the 2001 RAE in American Studies, and comparability with a much larger UoA, like English, became difficult. The sample size in USAmerican Studies is too small for anyone to mount any sort of effective challenge to the overall verdict, as statistical significance could not be demonstrated with any confidence. A clear consequence was that American Studies, on average, was arriving on average at low ratings-suggesting less high quality research was emerging from USAmerican Studies than was the case in many other UoAs, and this was especially true when it was compared with other Area Studies. This is starkly demonstrated in the following table. This compares, in four closely-related UoAs, the percentage of researchers located in "departments" in the UK 
scoring a high RAE Grade (Grade 5 or better) with the percentage scoring a lower RAE Grade (Grade 4 or less than Grade 4):

UoA Grade 5 or better Grade 4 or less Total researchers entered

American Studies 50.04\% 49.06\% 113.5 researchers

Middle East/African Studies 80.44\% 19.66\% 128.8 researchers

Asian Studies 77.38\% 22.62\% 129.5 researchers

European Studies $61.20 \%$ 38.80\% 558.7 researchers

The lower overall rating for Americanists is clear. ${ }^{7}$ It needs to be said that the national average for all UK researchers in all UoAs scoring a Grade 5 or better was $55 \%,{ }^{8}$ not that much more than-though, nevertheless, significantly more than-the average for American Studies (50\%). But when American Studies is compared with other Area Studies who entered about the same number of researchers (Middle East/African; Asian) the difference is huge (50\% compared to $75 \%$ plus). Even a very much larger UoA, European Studies-a UoA sufficiently large to be subject to "smoothing"-still had a much higher average-over $10 \%$ more.

What this meant in practice is that overall, nationally, American Studies received less government money in block grant form, and this is still the case year upon year. Indeed it will continue to be the case until 2009. It also meant that within each institution, American Studies was often rated lower than other "departments" and therefore it was less likely to be rated so highly by that institution's managers. On the face of it the RAE's verdict in 2001 was that much poorer research was being done in American Studies than was the case in, say, Chinese Studies or Russian Studies. I must just add that American Studies scholars in the UK contest this verdict bitterly.

But the knock-on consequences have been grim. As a consequence of RAE 2001's American Studies panel's relative conservatism in arriving at its gradings, and the resulting lack or reduction of research funding, one University's American Studies research team was disbanded (and its teaching team subsequently reduced to a rump by staff losses). Another only survived by implementing a drastic series of economy measures and increasing its teaching commitments substantially (and, again, some staff leakage resulted).

This impact of the RAE on American Studies also indicates how any overview (such as this one) of a subject's "national provision" needs to be alert to the institutional state apparatuses that frame the provision. Another such apparatus (though less of a state apparatus, perhaps), the British Association of American Studies (BAAS), has, in this respect, also been of decisive importance. Taking as its objective "to promote, support and encourage the study of the United States in the Universities, Colleges and Schools of the United Kingdom," BAAS was founded in 1955 by an "intimate" and "joll[y] ... band" of scholars, ${ }^{10}$ who believed, in the aftermath of World War Two, that the need to study the United States was inescapable-as unavoidable as the USA's final, overt acceptance of its World "super-power" role. BAAS was founded at an international conference on American Studies, the fourth such in the UK. Like the previous three, this conference was sponsored by the United States Education Commission (USEC). But US government involvement did not stop at sponsorship. Rather, a vision of American Studies in the UK was brought to this 1954 conference via the offices of the Cultural Attaché to the US Embassy in London, Dick Taylor and his participation on a UK 'ad hoc committee on American Studies' formed by USEC at that time. That USEC had been 
founded on the back of the Fulbright Act of 1946 is one sign of how the US saw its newly-warm embrace of its world role as incorporating a need to better educate the world about America. That USEC, via Taylor, now laid down some alluring financial come-ons to this ad hoc committee in the UK is another. Yet, as Scott Lucas and Ali Fisher have pointed out, what resulted is not any take-over or puppet-mastering by USEC or any other US institution. ${ }^{11}$ Rather, the UK members of the ad hoc committee resisted core elements of USEC's propositioning. They were, it is true, somewhat seduced by the promise of funding, and hurried into action by intimations that this offer of funding has a limited shelf-life. Yet they also shied away from the suggestion that BAAS should take on certain functions that would require it to assume a material as well as virtual existence-that is to say, to build up archives, study facilities and the like, that would necessitate the establishment of an institute-or, at least, an institute in all but name. What USEC was proposing would need housing; at one point a property called Ditchley Park was mentioned. ${ }^{12}$

This decision not to seek to establish an institute was a shrewd call. In India, for example, at about this time, a Fulbright agreement in 1950 established an exchange program of academics, and the USA helped ensure American Studies flourished via USEFI (the United States Educational Foundation in India). In 1964 this culminated in the establishment of the American Studies Research Center (ASRC) in Hyderabad, supported by the USA's State Department. In particular, the ASRC built up an impressive library. In 1996, however, the money ran out. The Center had been funded by a reversion (the money paid by India in the past for wheat it had received from the USA was now channeled by the USA's State Department into the ASRC). The decision to discontinue funding after this money ran out was devastating for the Indian ASRC. ${ }^{13}$ It is perhaps not too fanciful to suggest that such intellects as those of Dennis Welland, Malcolm Bradbury and H. C. Allen were alert to the risk that what they were being offered was 'front-end loading' of this kind (though in 1955 it would not have been called that): financial support that would cease to continue when BAAS was securely up and running. Instead, the nascent BAAS, cash-strapped and cautious, protractedly negotiated its way to a compromise. These negotiations were not directly with a US government agency, but with the Rockefeller Foundation. A lot of money was obtained, but no commitment to establish any kind of 'institute' was made. Instead the $\$ 150000$ over five years that the Rockefeller Foundation granted was to be spent on annual academic conferences, research fellowships, conferences for schoolteachers and the acquisition of research resources-but now resources to be dispersed across different UK universities and not concentrated in one central location. ${ }^{14}$ These negotiations were accompanied by some anxiety. Frank Thistlethwaite, founding chair of BAAS, at one time even contemplated looking this gift horse in the mouth, but in the end observed to Marcus Cunliffe, "I suspect that the reputation of the association might suffer ... from turning down such an offer." Thistlewaite feared that turning down the money would reduce the nascent organization to little more than "a talking shop." ${ }^{15}$ So it is fair to say that there is no "smoking gun" to be found. BAAS was not founded as a stool-pigeon of the US government's post-war ambitions to spread USAmerican Studies across the globe, whether its motives were quasi cultural imperialist or not. Yet BAAS was founded to counter the "condescension", "ignorance" and "prejudice" that dominated the British hegemonic establishment ${ }^{16}$. To this extent at least there was a congruence between what BAAS's founding members felt it should be about and what the US Government wanted it to achieve that was very productive for the latter. 
31 It must also be said that the residues of this anxiety-ridden foundation of BAAS remain visible. BAAS's infrastructure broadly echoes the objectives that the US government had in mind for it. BAAS still maintains a commitment to promoting the teaching of American Studies in schools and this is formally represented in the make-up of its Development Subcommittee and in how it deliberately reaches out to teachers in most of its activities (such as its conferences). Similarly, it continues to seek to develop resources, though now mostly by striking or seeking to strike deals with various kinds of publishers-microform publishers, internet publishers, academic publishers, textbook publishers-that often have at their heart archival developments, drawing on US-related archives in the UK. None of these activities are in the least bit objectionable or exceptional. Quite the reverse. The BAAS-backed BRRAM (British Records Relating to America on Microfilm), for example, has done sterling work for decades. Yet overall it does mean that BAAS's terms of reference extends well beyond the sort of remit that some professional academic associations possess (at least in the UK), which tends to foreground more exclusively academic research and its delivery. It is possible that, consequently, the sort of committee structure that BAAS possesses, with a conference committee, a development committee and a publications committee, means that it is set up to respond to government appeals for involvement in the various kinds of audit and quality-assurance activities that have come to the fore in UK HE in the 1980s and 1990s almost as well as it is set up to secure the development of a thriving American Studies research culture. BAAS's interests are more harlequin than they might have been had the US government's agenda not been vigorously represented at BAAS's birth. Almost, but not quite: I want to return to the BAAS and its research agenda in due course.

32 I think it is worth dwelling also on the trace of rebelliousness that not only caused BAAS to shy away from any subsumption within the US government's proselytizing agenda, but also from the condescension that the hegemonic establishment trained on their ex-colonists. This can be related to a widespread sense amongst young males in particular in the postwar period that the democratic, egalitarian, unceremonious, informal and above all friendly approach ostensibly espoused by the American servicemen they encountered during and after World War Two offered an antidote to the stuffiness, formality and hierarchicalism that these young British adults detected in the structures of post-war Britain. This sort of point is of course, perilously difficult to support, and pointing to Jimmy Porter's love of jazz in Look Back in Anger is not in itself sufficient to prove the point. Yet the election of a Labour government and the rejection of Winston Churchill's Conservatives in 1945, despite the (often over-estimated but still important) role that Churchill played in sustaining the morale of the British people during the War, does provide some sort of indication that impatience with the British establishment was quite widespread.

33 I do want to suggest, then, however tentatively, that British "class" distinctions played a part in the rise of American Studies. This is not a simple case of thinking in terms of Marxist class divisions. Marxist analyses are enabled by dividing up society into the bourgeoisie, the petit bourgeoisie, the proletariat and the lumpen proletariat (perhaps laced with an appeal to Gramsci's distinction between traditional and organic intellectuals). British "class" distinctions, by contrast, involve much more fussy and fuzzy differentiations, chiefly revolving around the invention of a middle class, itself subdivided. Turning to America enabled a freer intercourse between, across and 
through these fussily and fuzzily defined "class" gradations, that was refreshing to those who fwelt stifled by Britain's class-consciousness-even if this involved more than a few dollars worth of buying into the USAmerican exceptionalist dream. It all seemed more democratic "over there", and, residually, it perhaps still does. However, perhaps this residual sense of radical egalitarianism is no more than vestigial now, as the intake of American Studies students becomes increasingly middle class, as those from less socially-advantaged socio-economic groups shy away from acquiring four years of loans and debts rather than (merely!) three. Indeed one senior USAmericanists was recently (October 2005) heard to propose that what USAmerican Studies now provided was a species of "finishing school" for females from well-heeled families. This sexist observation was not without a thick residue of merit. It is largely the case that USAmerican Studies is dominated by the late-adolescent children of the middle class, and it is true that in many USAmerican Studies "Departments", those centered more on History/Literature/ Culture/Media Studies than on History/Politics/ International Relations/Geography, the intake is predominantly female. More than incidentally, this also means the intake is predominantly "white"-despite the strength of ethnic studies of various kinds in UK USAmerican Studies provisions.

This gender and class bias does have consequences. At undergraduate level the courses that recruit most heavily are those that feature literary, cultural and media studies. This in turn influences hiring policies, and a kind of self-perpetuating shift in the overall emphasis of USAmerican Studies results. The annual BAAS conference, for example, is now dominated by sessions on topics related to literary, cultural and media studies. A more-or-less conscious effort is being made by the USAmerican Studies community in the UK to address this drift. In this respect it is possible to argue that the Bush Presidency, far from having a negative impact on USAmerican Studies in the UK, is having a positive effect, by bringing political, diplomatic and international considerations to the forefront of students' minds-re-radicalizing them, if you like.

I do sense that there is currently a growing discussion about how USAmerican Studies needs to be proactive in sustaining a balance in its curricula between a vital engagement with issues of gender, ethnicity and race and their discursive and performative representations in USAmerica's cultural apparatuses on the one hand and the need to sustain an engagement with other (inter-)disciplinary perspectives and analytical approaches on the other. However I also sense that this debate is not new, nor as complete as it might be. Religion and law feature too infrequently, perhaps, but the clearest omission is an engagement with the issue of language competency. There are of course, systemic reasons for this, not least to do with the necessary concession that English is sited at the forefront of the list of global languages. The nearest other contenders are Spanish and Chinese (the British Empire and its legacies have a lot to do with this, needless to say). Yet Chinese is perhaps falling away, as more and more commonly Chinese industries insist upon English being spoken throughout their operations-even in China itself. ${ }^{17}$ Spanish is perhaps the most plausible exception to simply (if reductively) passing the verdict that English's global dominance is unassailable, and it is important to notice that the use of Spanish in the USA figures prominently in arriving at this verdict. Yet USAmerican Studies in the UK has hardly responded at all to the increase in the use of Spanish within the USA's borders. Generally these is no requirement, or only a minimal requirement, for USAmerican 
students at whatever level to engage in second language study. This must be a bad thing.

The only glimmer of hope I can offer at this point is to observe that students do come to question the "naturalness" of language and to recognize both its arbitrariness and its conventionality by encountering what Lawrence Ferlinghetti once described as the "barrier of the common language." ${ }^{18}$ This is of course not just a matter or sorting out sidewalks from pavements, cookies from biscuits nor trunks from boots (nor, even, M \& Ms from Smarties). It is of course to do with more complex and nuanced shadings, which persistently drive home to USAmericanist students in the UK the cultural differences between US English speakers and UK English speakers. Often, UK whites' reliance on irony and self-deprecation in their humor, and USAmerica's frequent failure to crack even a responsive smile in return has something to do with this breakthrough. I wish I could claim that, newly alerted to these complexities of language, the UK's USAmerican students rushed off to the language laboratory. They don't; but they have learned something about inter-cultural competence.

Yet if encountering cultural difference doesn't quite set UK students of USAmerica off down the road towards second language acquisition it does at least make them realize how wide the Atlantic pond is. Perhaps it also establishes a comparative reflex within them. For, besides studies revolving around ethnicity, race, gender and their articulations in the cultures of the USA, an arena which continues to attract students, perhaps now more than ever, is Atlanticism-study of the various Atlantics, their exchanges, crossings, currents and flows. In this arena, the list of approaches is long and growing. This involves not just the transatlantic but also the circumatlantic and the cis-atlantic; and not just the New England and/orWASP Atlantic so long a center of attention, but also the Black Atlantic, the Red Atlantic, the Green Atlantic, the Jewish Atlantic, et cetera. There has been a big upsurge in attention, marked by a long series of initiatives. Though it is a little invidious to pick out a few, it is best I do so: the Scottish Trans-Atlantic Relations Project (STAR); UK involvement in the Maastricht Center for Transatlantic Studies; the recent founding of the Transatlantic Studies Association (TSA); the recent founding of both Atlantic Studies: Literary Cultural and Historical Perspectives and the Journal of Transatlantic Studies, the organ of the TSA-two new journals now arranging themselves alongside Symbiosis: A Journal of Anglo-American Literary Relations, ${ }^{19}$ et cetera. I think it is plain that there is more than a little overkill in all this. The attendant risk in all this attention poured upon the Atlantic is that other crucial developments will get somewhat passed by: for example, scant attention is being paid overall to the emerging importance of the Pacific Rim and the attendant-let us coin the phrase-Pacificisms that are beginning to emerge, with, for example, Hawai'i as one fulcrum of this re-orientation.

One can see just why the Atlantic is so dominant. The UK's colonial links to the USA and its continued retention of Canada and the West Indies long after the end of the USAmerican War of Independence deeply implicates the UK in Atlantic trades, profits, losses, exploitations and commodifications-especially slavery. The Atlantic trade was central to the UK's assumption of modernity, and remains central to its transnational engagements. But such a concentration has generally ensured relatively little nonUSAmerican Studies occurs. Simply put, other American Studies are thin on the ground; what Canadian Studies there is (and it is relatively strong when set alongside the provision for Central and South American Studies) depends substantially on an 
enlightened Canadian government policy of supporting Canadian Studies in the UK over the long term, on a continuing basis. There is some teaching of the Americas, as witnessed by the existence in London of the Institute for the Study of the Americas, which incorporates the Institute of Latin American Studies, and in the provision in Latin American Studies offered by the University of Liverpool in particular. But otherwise, when gauging the kinds of interests in the Americas that are active in terms of the UK research centers that exist, things are pretty resolutely defined by Anglophone American Studies' predomination. Thus we have the David Bruce Centre for American Studies at the University of Keele, the Andrew Hook Centre for American Studies at the University of Glasgow and (in a more limited way, as its name suggests) the Arthur Miller Centre at the University of East Anglia. Symptomatically, even the Institute for the Study of the Americas incorporates alongside the Institute for the Study of the Americas the Institute for United States Studies. Each of these is to a greater or lesser extent cash strapped, though to say this is not to denigrate the important work they do. The only two centers that have any sort of budget are the Eccles Centre for American Research and the Rothermere American Institute. ${ }^{20}$ Both these have substantial bequests providing them with an income providing some stability-the Eccles Centre from Lord and Lady Eccles, the Rothermere from Lord Rothermere. There is some irony in this, for these titled benefactors chose locations for their bequests that are not entirely appropriate. The Eccles Centre is based at the British Library, which has, conspicuously, recently decided to rein back on its expenditure on USAmerican publications (though its library does possess some significant American archives-particularly early maps of the Americas). Even more disconcertingly, the very much more wealthy Rothermere American Institute is based in Oxford University, an institution which has no real tradition of study of USAmerica, relatively few researchers working concertedly in this area and no American Studies provision (though some postgraduate provision is now being developed; the institute has only recently been established, it must be added). It is difficult not to conclude that the class-ridden contours of English society influenced the decision about where these well-endowed research centers should be located. The provinces-outside the so-called "golden triangle" of London Cambridge and Oxford could hardly be considered, even though the commitment of Liverpool, Birmingham and Nottingham were more longstanding and thoroughgoing. These centers stand alongside the Scottish Transatlantic Research project, the Dundee Transatlantic Association and the (very recently founded) Centre for Foreign Policy, Media and Culture at Birmingham to define American Studies in the UK, once all these centers are set alongside the American Studies programs (for American Studies, almost always read USAmerican Studies, as ever) that exist in many of the Universities in the UK. ${ }^{21}$

39 Yet it is in fact difficult to measure the size of the USAmerican Studies community with any accuracy, since so many of the USAmerican Studies programs in the UK are delivered not in distinct "Departments" but by ad hoc groups of staff arranged in loose coalitions (as previously mentioned). Accordingly any survey of the resulting patchwork undergraduate provision becomes difficult.

40 A few generalizations can be attempted, based on how this provision is "sold" to prospective students: the transatlantic is (unsurprisingly) often flagged as a feature; film studies and ethnic studies, especially African American and Native American studies are frequently vaunted; single honours degrees usually involve four years of study with a year (the third) spent in USAmerica-usually in University exchanges, with 
California most frequently specified; and much mention is made of adopting multidisciplinary and interdisciplinary approaches. The contours of this engagement are usually not clearly laid out, but rather baldly claimed. It is perhaps true to say that often the under-specified interdisciplinary approach that is deployed is informed by UK humanities' widespread embrace of three main strands of theory. One derives from European Marxist and post-structural theorists (Gramsci, Foucault, Derrida, Benjamin, Kristeva, et cetera). The second stems from what might be described as British Cultural Studies (Richard Hoggart, Raymond Williams, Stuart Hall and Paul Gilroy) and the last from postcolonial theorists (Said, Bhabha, Spivak, Robert Young). US theorists, like Fredric Jameson, Edward Soja, Mary Louise Pratt, are most commonly taken up insofar as they engage with one or more of these theoretical strands.

41 Such rapid summarizing runs the risk of sounding dismissive. I must therefore take pause to stress the variety of research that occurs in the UK. It is a varied and dynamic research scene, and this is reflected in a rich provision, despite the recent emphasis upon the Atlantic (and even if the Atlantic comes to dominate even more when graduate provisions are added in to the survey). British USAmerican Studies is, thank goodness, far from drawn up along comparitivist lines. The siren voices that often unthinkingly emerge from the USAmerican academy-urging that, say, a non-US student of USAmerican Studies working in the UK and interested in William Burroughs, should focus upon him and his work comparatively, drawing upon and researching Burroughs' long engagement with the UK literary, cultural, social (and medical) scene and excavating relevant UK archives-are very far from always heeded. Heeding these voices would certainly produce some sort of comparativist ghetto, into which non-US scholars could be (safely) lump[en]ed, leaving the "real" research to be done by USAmericans, in the US. Consequently, and rightly, much emphasis in the UK is placed upon finding ways of sending UK academics across the Atlantic pond to carry out primary research.

However, I would want to urge again that in Europe-and beyond Europe-there is much room for further properly international collaboration and co-operation. The aim of this should not be just to take account of the new interest in the transnational in USAmerican Studies or the importance of globalization, though both these should certainly constitute a main element of such developments. Rather, World American Studies should also aim to come together to help define what perspectives result from studying USAmerica from the outside, untrammeled by an increasingly confident, interventionist and censorious neo-conservative and "moral majority" USAmerican minority that perhaps does somewhat rein in USAmericanists in the USA.

For this reason I am bound to end this article by suggesting that the European Journal of American Studies country-by-country survey of USAmerican Studies in Europe is fundamentally misconceived-even retrograde. Rather this brand new journal of American Studies in Europe, in which this essay appears, should be considering larger questions, to do with the transnational, the global, and how American Studies scholars outside of the States may be particularly fortunately positioned to take on USAmerican Studies at this point in this field's development. 


\section{NOTES}

1. Polly Toynbee, 'A degree in bullying and self-interest? No thanks', The Guardian Wednesday 25 August 2004, http://education.guardian.co.uk/higher/comment/story/ 0,1290138,00.html [accessed 01/11/2005].

2. The conflation USAmerica[n] is taken from Malim Johar Schueller. I agree with him that 'American' as an adjective and 'America' as a noun should only be deployed in hemispheric usages. See Malim Johar Schueller, U.S. Orientalism: Race, Nation and Gender in Literature (Ann Arbor, MI: University of Michigan Press), 1998. In this article, also, I will view American Studies as a subject, an Area Study, rather than as a discipline. I regard American Studies as an interdisciplinary endeavor, though one always embracing at times, strategically, disciplinary and multi-disciplinary perspectives as well. I return to this issue near the end of my article.

3. Walt Whitman, "Song of Myself", Leaves of Grass 1855, rpt. Harmondsworth: Penguin, 1975, 123.

4. Toynbee, op. cit.

5. Rebecca Smithers, "80\% against student top-up fees," The Guardian 9 September 2003. http://educationguardian.co.uk/students/tuitionfees/story/0,12757,1038519,00html [accessed 30/9/2005].

6. David Crystal, English as Global Language, Cambridge: Cambridge UniversityPress, 11-26.

7. See http://www.hefce.ac.uk/research/assessment/ [accessed 30/9/2005]

8. The scores were actually amalgamated to become "departmental" scores, and these departments' ratings were then calculated overall as a composite of the research submitted, the research environment and esteem indicators. Consequently the phrase "percentage of researchers located in 'departments' in the UK" is an important qualification.

9. http://www.baas.ac.uk/administrastion/admin.asp [accessed 5 November 2005]

10. Herbert Nicholas, "The Education of an Americanist," Journal of American Studies 14 (April 1980): 24.

11. Scott Lucas and Ali Fisher, "Master and Servant? The US Government and the Founding of The British Association of American Studies," European Journal of American Culture, 21.1 (2002): 16-25.

12. Lucas and Fisher, 18.

13. See Manju Jaidka, "American Studies in India: a retrospect," Comparative American Studies 2.4 (December 2004): 461-469.

14. Lucas and Fisher, 22-23.

15. Frank Thistlethwaite to Marcus Cunliffe, 9 February 1957, BAAS archive, University of Birmingham Library Special Collections, Box 1 B1.

16. See Richard King, "Present at the Creation: Marcus Cunliffe and American Studies," Journal of American Studies 26 (1992): 265; David Reynolds, "Whitehall, Washington and the Promotion of American Studies in Britain during World War Two," Journal of American Studies 16 (August 1982): 166.

17. This assertion is based upon my own observations when in China in 2002 and 2003.

18. Personal communication to R. J. Ellis, 2 September 1997. 
19. See http://www.star.ac.uk; http://www.cmsu.edu/mcts/index.cfm; http:// www.personal.dundee.ac.uk/ awparker/transatlantic.html; http://www.tandf.co.uk/ journals/titles/14788810.asp; http://www.dundee.ac.uk/iteas/journal.htm; http:// www.symbiosisonline.org.uk. All accessed 30/9/2005.

20. http://www.keele.ac.uk/depts/as/Dbruce/bruce.htm; http://www2arts.gla.ac.uk/ CAS/; http://www.uea.ac.uk/eas/centres/miller/miller.intro.shtml; http:// americas.sas.ac.uk; http://www.rai.ox.ac.uk/; http://www.bl.uk/collections/americas/ american.html. All accessed 30/9/2005.

21. http://www.star.ac.uk; http://www.personal.dundee.ac.uk/ awparker/tsa.htm; http://www.ifpmc.bham.ac.uk. All accessed 30/9/2005.

INDEX

Keywords : interdisciplinarity, Film Studies, Native American, African-American, ethnic studies, USAmerican Studies 